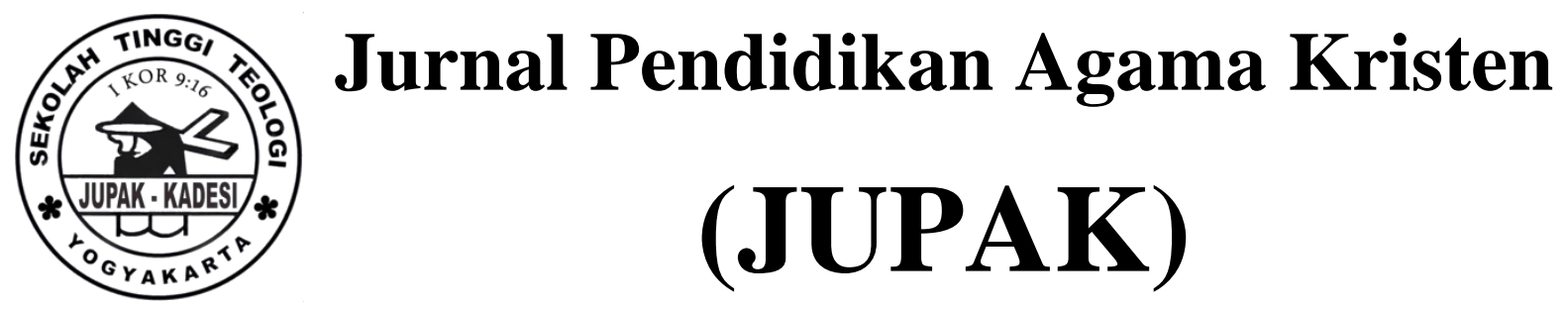

Vol. 1 No. 1 (December 2020) hlm. 57-78

Jurnal Pendidikan Agama Kristen (JUPAK)

e-ISSN 2774-3861

https://ejurnal.sttkadesiyogyakarta.ac.id/index.php/jupak

p-ISSN 2774-6399

https://doi.org/10.52489/jupak.v1i1.6

\title{
Landasan Psikologis Pendidikan Kristen dan Relevansinya dalam Pendidikan Kristen Masa Kini
}

\section{Paulus Kunto Baskoro}

Sekolah Tinggi Teologi Anugerah Allianse Semarang, Surakarta, paulusbaskoro1177@gmail.com

\section{Recommended Citation}

Turabian $8^{\text {th }}$ edition (full note)

Paulus Kunto Baskoro, "Landasan Psikologis Pendidikan Kristen Dan Relevansinya Dalam Pendidikan Kristen Masa Kini," Jurnal Pendidikan Agama Kristen (JUPAK) 1, no. 1 (December 4, 2020): 1, accessed August 6, 2021, https://ejurnal.sttkadesiyogyakarta.ac.id/index.php/jupak/article/view/6.

American Psychological Association $7^{\text {th }}$ edition

(Baskoro, 2020, p. 1)

This Article is brought to you for free and open access by Sekolah Tinggi Teologi Kadesi Yogyakarta. It has been accepted for inclusion in Christian Perspectives in Education by an authorized editor of Jurnal Pendidikan Agama Kristen (JUPAK).

For more information, please contact juniorichson1995@gmail.com 


\begin{abstract}
Building a family, church, educational institution or business world cannot be separated from the concept of an education. Education is an important reference in seeing, directing and bringing about a very significant and maximum change. By using descriptive descriptive method, through the literature study approach, research can describe the journey of education in a person, family, educational institution, church or business world, which cannot be separated from the psychological element which is the basis for further understanding. This is because there are many people who have not taken Christian education seriously in the family, work environment, even in churches with a clear curriculum. In the context of this discussion, education is focused on Christian education. It is very necessary to build a strong psychological foundation in Christian education, so that it can be used as a reference in building an ideal and maximum Christian education. The principles in this presentation will formulate some of the psychological foundations which are the foundation of Christian education. Because Christian education is very important in building a wholeness of view that is in accordance with the truth of God's Word and the character of Christ.
\end{abstract}

Keywords: Psychological Basis, Christian Education, Present

\begin{abstract}
Abstrak
Membangun sebuah keluarga, gereja, lembaga pendidikan atau dunia bisnis, tidak bisa dilepaskan dengan konsep sebuah pendidikan. Pendidikan menjadi acuan penting dalam melihat, mengarahkan dan membawa sebuah perubahan yang sangat signifikan serta maksimal. Dengan menggunakan metode kulitatif deskritif, melalui pendekatan studi pustaka penelitian dapat mendeskripsikan perjalanan pendidikan dalam diri seseorang, keluarga, lembaga pendidikan, gereja atau dunia bisnis, tidak bisa dilepaskan dengan unsur psikologi yang menjadi modal dasar pemahaman selanjutnya. Sebab jika dilihat ada banyak orang yang belum menerapkan pendidikan Kristen dengan serius dalam keluarga, lingkungan pekerjaan, bahkan dalam gereja dengan kurikulum yang jelas. Konteks pembahasan ini, pendidikan difokuskan kepada pendidikan Kristen. Sangat dirasa perlu untuk membangun sebuah landasan-landasan psikologis yang kuat dalam pendidikan Kristen, sehingga bisa dijadikan sebagai sebuah acuan dalam membangun pendidikan Kristen yang ideal serta maksimal. Prinsip-prinsip dalam pemaparan ini yang akan merumuskan beberapa landasan-landasan psikologi yang merupakan pijakan dalam pendidikan Kristen. Sebab pendidikan Kristen menjadi sangat penting dalam membangun sebuah keutuhan pandangan yang sesuai dengan kebenaran Firman Tuhan serta karakter Kristus.
\end{abstract}

Kata kunci: Landasan Psikologis, Pendidikan Kristen, Masa Kini 


\section{PENDAHULUAN}

Pendidikan menjadi bagian terpenting dalam seluruh aspek kehidupan. Baik itu pendidikan secara formal, maupun pendidikan non formal. Sebab pendidikan yang berhubungan nilai-nilai kekristenan memiliki pengaruh yang sangat besar dalam sikap dan tingkah laku (Ermindyawati 2019). Baik itu pendidikan dalam keluarga, gereja, dunia kerja, maupun pendidikan dalam segala sisi kehidupan. Terlebih lagi pendidikan terhadap diri sendiri. Pendidikan menjadi bagian terpenting sebab dapat mengubah cara pandang seperti yang nyata dalam Roma 12:1-2. Rasul Paulus mau menyatakan bahwa pikiran menjadi bagian terpenting untuk sebuah perubahan dalam kehidupan. Pendidikan menjadi salah satu faktor pikiran mengalami perubahan. Sebab ini adalah tugas yang terpenting sebagai pendidikan dalam tujuan pembelajaran untuk memunculkan generasi yang serupa dengan Kristus dan pikiran yang mulia (Telaumbanua 2018).

Dan untuk membangun sebuah pendidikan, fokus penulis bagian ini adalah pendidikan Kristen yang bersumber kepada kebenaran Firman Tuhan, sebab Firman Tuhan yang menuntun kehidupan orang percaya dan menjadi sentral kebenaran yang paling hakiki serta utuh terlebih bahwa Alkitab sebagai dasar fondasi kerohanian.(Y. A. Arifianto 2020a) Dan juga pendidikan Agama Kristen adalah hal yang urgent untuk meningkatkan kekuatan spiritual dan menjadi kekuatan iman yang serius dengan Tuhan (Ermindyawati 2019).

Ketika pendidikan Kristen menjadi hal yang serius untuk dikerjakan maka akan terjadi dampak yang besar, baik dalam diri seseorang, keluarga, gereja, instansi tertentu dan kehidupan dalam sosial masyarakat (Sahartian 2018). Pendidikan Kristen yang terbaik juga perlu dilihat juga dari psikologisnya, supaya pendekatan yang dilakukan dalam mendidik kepada peserta didik dapat lebih efektif dan maksimal. Berharap dengan mengetahui landasan-landasan psikologisnya, maka akan sangat dimungkinkan pendidikan Kristen yang dibangun menjadi lebih kokoh dan kuat, bahkan serius dalam membentuk karakter setiap orang (Telaumbanua 2018). Hal inilah yang akan menjadi sentral pembahasan dalam makalah ini, yang akan meninjau pengertian psikologi pendidikan Kristen serta mengupas landasan-landasan dasar psikologi berdasarkan kebenaran Firman Tuhan. 


\section{METODE}

Penelitian ini menggunakan metode kulitatif deskritif,(Zaluchu 2020) yaitu mempelajari tentang landasan psikologis Pendidikan Kristen dan relevansinya dalam Pendidikan Kristen. Penulis menggali kebenaran-kebenaran secara studi teologis tentang konsep pendidikan Kristen. Dengan didukung fakta dilapangan dengan penelitian studi literatur atau studi pustaka untuk memperkokoh sebuah pemahaman tentang landasan psikologis pendidikan Kristen dan relevansinya dalam pendidikan Kristen masa kini, sehingga memiliki dasar teologi yang kokoh, serta pelaksanaan yang efektif dalam pendidikan baik di keluarga, orang percaya maupun gereja Tuhan.

\section{PEMBAHASAN}

\section{Pengertian Psikologi Pendidikan Kristen}

Untuk dapat memahami secara maksimal landasan-landasan psikologis pendidikan Kristen, maka perlu dipahami pengertian awal, baik tentang pendidikan Kristen, maupun apa itu yang dimaksud psikologi. Memahami makna pendidikan Kristen akan dikaji secara mendalam arti pendidikan Kristen, fungsi pendidikan Kristen serta pendidikan Kristen dalam Perjanjian Lama serta Perjanjian Baru (Hastuti 2013). Kemudian dikaji juga tentang makna psikologis pendidikan yang di pikirkan juga tentang arti psikologi, arti psikologis pendidikan, sejarah psikologis pendidikan, fungsi psikologis pendidikan dan wilayah terapan psikologis pendidikan. Sehingga pengertian-pengertian awal ini dapat merumuskan pengertian yang utuh tentang psikologis pendidikan Kristen.

\section{Arti Pendidikan Kristen}

Pendidikan Kristen menjadi bagian terpenting dalam sharring makalah ini, sebab ini akan sangat bermanfaat bagi pribadi, keluarga, gereja dan semua orang percaya. Serta ini memiliki kekuatan mulia dalam menunaikan pelayanan (Widianing 2018). Menurut Kamus Besar Bahasa Indonesia, kata pendidikan dari kata dasar "didik" memiliki arti, "memelihara, memberi latihan, menuntun, mengajar dan memimpin." Jadi pendidikan, yaitu "proses perubahan sikap atau tata laku seseorang atau kelompok orang, usaha mendewasakan manusia melalui upaya pengajaran dan pelatihan, proses, cara, perbuatan mendidik"(KBBI 2002:263). Sedangkan Kristen menurut Kamus Besar Bahasa Indonesia, yaitu : "agama yang 
disampaikan oleh Kristus, serta menyangkut agama Kristen.”(KBBI 2002). Jadi pendidikan Kristen adalah sebuah proses perubahan sikap atau tata laku dari orang yang percaya Kristus, atau orang Kristen yang dilakukan dengan upaya untuk pendewasaan dengan pengajaran dan pelatihan.

Menurut Robert W. Pazmino, pendidikan Kristen adalah usaha untuk memikirkan praktik pendidikan secara bertanggungjawab dari sudut pandangan teologi Injili, orang Kristen dan secara khusus pada pendidik Kristen dan yang dengan serius memperhatikan dengan sungguh-sungguh pondasi Alkitabiah yang mendasarkan praktek pendidikan Kristen (Pazmino 2016). Sehingga pendidikan yang bersumber kepada Alkitab akan menghasilkan pribadi-pribadi pengikut Kristus yang maksimal karena mendapatkan pendidikan yang sangat tajam, efektif dan kreatif.

Disisi lain, pendidikan Kristen bisa diterjemahkan bahwa proses dalam nama gereja berusaha untuk menyanggupkan anggota-anggotanya mengerti dan menerima serta meneladani iman dan cara hidup Kristen. Ini adalah usaha untuk menyanggupkan mereka mengerti arti sepenuhnya dan kemungkinan-kemungkinan dari sifat manusia sebagaimana diungkapkan dalam Yesus Kristus. Bertalian dengan pengetahuan modern, usaha-usaha ini membantu mereka mengadakan dan memelihara hubungan dengan Allah dan dengan orangorang lain yang dapat mengarahkan mereka kepada perwujudan dari potensi mereka. Dan terus memotivasi untuk mengembangkan, sebab ketika motivasi kuat, maka setiap hal yang dilakukan akan selesai dengan sempurna (Saptono Yohanes Joko 2016). Juga membantu mereka dalam usaha yang terus menerus untuk merealisasikan kehendak dan maksud Allah bagi mereka dan bagi seluruh umat manusia, terutama bagi orang percaya. Menurut Hardi Budiyana, pendidikan Kristen yaitu bantuan yang dilakukan dengan sadar atau sengaja kepada anak didik agar supaya didalamnya mereka bertumbuh dan berkembang mencapai kedewasaan secara susila dan nilai-nilai kekristenan atas dasar iman Kristen (Budiyana 2017). Dan berdampak untuk membawa jiwa dan memulihkan orang yang terhilang (Y. A. Arifianto 2020b).

\section{Fungsi Pendidikan Kristen}

Pendidikan menjadi dasar dalam segala aspek kehidupan, itu sebabnya betapa pentingnya sebuah pendidikan, terutama pendidikan Kristen. Fungsi pendidikan Kristen yaitu: membawa orang percaya pada kedewasaan dalam Kristus Yesus, orang percaya 
mengerti yang sesungguhnya tentang dirinya sendiri, orang percaya dapat menguasai segala sesuai yang ada dalam potensi didalam dirinya sendiri, orang percaya mengarahkan dirinya dan segala yang dikerjakannya kepada Allah, menjadikan setiap orang percaya memiliki karakter seperti Yesus Kristus dan mengerti arti sebuah kehidupan (Tafonao 2018). Dan juga pelayanan dan pengajaran Yesus menegaskan bahwa kasih yang sejati bukanlah pengetahuan agama tetapi praktik dan perilaku kasih yang terlihat pada siapapun, terlebih pada "mereka" yang membutuhkan (Y. Arifianto 2020), dan hal ini juga menjadi fungsi yang berarti.

Fungsi yang sangat kuat ini yang akan menjadikan dirinya, keluarga, gereja bisa kokoh dan kuat serta berfungsi dalam kegerakan anggota tubuh Kristus dan nama Tuhan dipermuliakan. Dan yang terpenting dalam segalanya, Injil terus menjadi berita yang sangat luas. Serta sedemikian rupa akhirnya menghasilkkan peserta didik, khususnya orang percaya yang bisa mengevaluasi segala sesuatu yang dihadapi dalam terang Firman Tuhan yang memunculkan nilai spiritual (2 Tim. 2:15) (Lase and Hulu 2020).

\section{Ciri Khas Pendidikan Kristen}

Kekuatan pendidikan Kristen, menjadi sentral kehidupan Kristen. Dan ciri khas pendidikan Kristen yaitu : pendidikan Kristen didasarkan atas kebenaran konsep Kristen dalam hubungan Allah dengan manusia atau sebaliknya, pendidikan Kristen, memiliki unsur mutlak berdasarkan pengertian Firman Tuhan, fokus pendidikan Kristen adalah berdasarkan kepada pribadi-pribadi, pendidikan Kristen berlaku bagi gereja Tuhan terutama keluargakeluarga di dalam gereja tersebut, kemanusiaan pendidikan Kristen berpusat kepada gambar Allah, pendidikan Kristen berpusat kepada karakter Kristus, pendidikan Kristen berfokus kepada interaksi, displin pendidikan Kristen berfokus kepada kasih, pendidik pendidikan Kristen berpusat kepada Kristus, pendidikan Kristen berfokus juga kepada evaluasi yang membawa pertumbuhan dan kedewasaan.

\section{Makna Psikologi Pendidikan}

Pendekatan yang efektif dalam pendidikan menjadikan konsep pendidikan sangat maksimal untuk diterapkan. Sehingga terjadi sebuah perubahan yang sangat fundamental dalam kehidupan seseorang (Heath 1995:26). Maka hal itu perlu dimaknai sebagai berikut: 


\section{Arti Psikologi dan Psikologi Pendidikan}

Memahami psikologi pendidikan, harus dikaji lebih dahulu arti psikologi, menurut Kamus Besar Bahasa Indonesia, psikologi yaitu : ilmu yang berkaitan dengan proses mental, baik normal dan abnormal, dan pengaruhnya kepada perilaku serta ilmu pengetahuan tentang jiwa. Sedangkan psikologis yaitu berkenaan dengan kejiwaan (KBBI 2002). Psikologi berasal dari bahasa Yunani yaitu " $\pi \sigma \theta \chi \eta \varepsilon "$ (psukhe) yang berarti berdarah panas fokus kepada jiwa

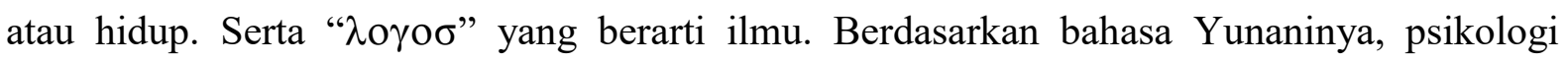
berarti ilmu kejiwaan, perilaku dan tingkah laku manusia.

Menurut beberapa ahli pengertian psikologi pendidikan yaitu : Wherington berkata, "Psikologi Pendidikan yaitu studi sistematis tentang proses-proses dan faktor-faktor yang berhubungan dengan pendidikan manusia, yang mana Sumadi Suryabrata, juga menyatakan, "Psikologi Pendidikan yaitu pengetahuan psikologi mengenai anak didik dalam situasi pendidikan," demikian juga Elliot berkomentar, "Psikologi Pendidikan yaitu penerapan teoriteori psikologi dalam mempelajari perkembangan, belajar, motivasi, pengajaran dan permasalahan yang muncul dalam dunia pendidikan," bahkan lebih tegas Anita Woolfok Hoy, "Psikologi Pendidikan yaitu ilmu yang memfokuskan perhatiannya pada proses belajar dan pembelajaran, menerapkan metode dan teori psikologi dan menjadikan menjadi teori secara kesesuaian," dan dipertajam oleh Santrock, "Psikologi Pendidikan yaitu pemahaman tentang proses belajar dan mengajar dalam lingkungan pendidikan.”

Jadi psikologi pendidikan adalah sebuah pendidikan yang secara serius mengkaji proses mental dan pengaruhnya bagi perilaku kejiwaan seseorang, sehingga karakteristik seseorang bisa lebih dipahami dalam perkembangannya. Hal ini sangat diperlukan untuk memahami secara utuh untuk membawa seseorang kepada tingkatan pertumbuhan atau kedewasaan hidup, khususnya hidup rohani, sehingga mereka cakap untuk menjadi pribadi yang melaksanakan kebenaran Firman Tuhan. Karena kekuatan pemahaman Firman Tuhan yang menjadi dasar kekuatan sebuah kehidupan (Sahartian 2018).

\section{Sejarah Psikologi Pendidikan}

Beberapa proses yang memulai psikologi pendidikan dari beberapa tokoh psikologi yaitu : Democritus - Abad ke 5 SM, yang menyatakan menuliskan manfaat tindakan dari sekolah dan pengaruh lingkungan rumah pada keberhasilan belajar individu. Plato dan Aristoteles - Abad ke 4 SM, menyatakan mempelajari beberapa topic dalam pendidikan, 
seperti karakter, latihan-latihan jasmani, peran guru, relasi guru dan murid, efek dari music, puisi dan seni, jenis aktifitas belajar. Johan Amos Comenius - Tahun 1592, menyatakan jangan menganggap anak menjadi miniature orang dewasa, serta pembelajaran harus menjadi menarik bagi anak-anak seperti dengan adanya alat peraga. Jean Jaques Rousseau - Tahun 1712, menyatakan penting untuk menyatakan bahwa sesuatu dari Sang Pencipta sangat baik, namun menjadi buruk ditangan manusia, campur tangan orang tua menentukan kehidupan seorang anak, dan setiap peserta didik harus memperlengkapi diri dengan memahami kejiwaan peserta didik (Sahartian 2018).

\section{Fungsi Psikologi Pendidikan}

Fungsi psikologi pendidikan sangat penting, yaitu melihat kebutuhan kepekaan terhadap perilaku manusia, dapat dengan cepat mengatasi problem kejiwaan yang ada dalam peserta, mengetahui secara cepat gelaja yang muncul, mengembangkan diri dengan maksimal berdasarkan ilmu terapan, namun bukan saja secara pemahaman pikiran tapi juga transfer dan impartasi iman,(Samosir 2019) potensi belajar akan maksimal dengan memahami tehnik yang tepat serta efektif, serta dikenali dengan baik, mengevaluasi kelebihan dan kekurangan dalam setiap proses pendidikan yang sedang berlangsung baik dari sisi yang mengajar maupun yang diajar, meningkatkan semangat dalam belajar, munculnya sebuah dorongan untuk generasi selanjutnya bisa belajar lebih cerdas dan maksimal, program yang sudah dicanangkan akan terselesaikan dengan baik dan menjadikan seluruh visi menjadi tercapai dengan maksimal, terjadi terobosan-terobosan baru dalam proses pendidikan, sehingga makin banyak hal baru yang terwujud dan makin kreatif, meskipun dalam masa sulit (Casriarno and Nataniel 2020).

\section{Wilayah Terapan Psikologi Pendidikan}

Pendekatan dalam Psikologi Pendidikan yaitu, Pertama, Teori Perkembangan Psikologi Kognitif (Bruner), yang fokusnya mengutamakan bagaimana cara mengembangkan fungsi kognitif individu sehingga bisa belajar dengan maksimal, mempengaruhi perkembangan peserta didik sebagai tolak ukur kesuksesan proses pembelajaran dan merupakan teori yang berfokus kepada proses belajar. Kedua, Teori Perkembangan Psikologi Behavioristik (Behaviorisme), yang berfokus kepada Salah satu teori yang berkembang dalam dunia pendidikan dan pembelajaran, pengamatan terhadap perubahan perilaku 
pengaruh peristiwa di luar, individu yang belajar dengan baik dan serius akan mendapatkan hasil kualitas yang terbaik dari belajarnya. Ketiga, Teori Perkembangan Psikologi Humanisme (Carl Roger), yang berfokus kepada mengutamakan keterlibatan individu secara keseluruhan dengan melibatkan kekuatan emosional peserta didik dan memilih proses pembelajaran dan menilai sendiri hasilnya sehingga memberikan motivasi tersendiri untuk terus belajar secara positif. Keempat, Teori Perkembangan Konstruktivisme, yang berfokus untuk mendapat transfer ilmu dari pengajar, karena belum mengetahui apa yang sedang diajar dan memiliki bekal yang sangat penting untuk mengembangkan selanjutnya dari ilmu yang didapat dan menjadi sesuatu yang baru serta menjadi sebuah pengetahuan atau ide yang utuh dan baru. Dan pendidik memiliki tanggung jawab penting membawa setiap orang yang didampingi untuk bertumbuh dengan tiga aspek penting (kognitif, afektif dan psikomotorik) sesuai Firman Tuhan (Sahartian 2018).

\section{$\underline{\text { Arti Psikologi Pendidikan Kristen }}$}

Jadi melihat pemaparan diatas tentang pendidikan Kristen dan psikologis pendidikan, maka dapat disimpulkan Psikologi Pendidikan Kristen, yaitu memahami bentuk-bentuk gejala kejiwaan, sikap dan perilaku orang Kristen, baik secara pribadi atau dalam lingkungan gereja, dalam proses pendidikan atau selama mengikuti belajar mengajar, sehingga kelihatan potensinya dan mengembangkan potensi yang sesungguhnya untuk memfokuskan individu tersebut dalam semua tujuan pembelajaran dengan hasil yang sangat efektif dan maksimal. Jadi harus menikmati sebuah prosesnya dalam pembelajaran (Hendro H. siburian 2019).

Psikologi dalam pendidikan Kristen merupakan pengkajian perilaku peserta didik atau umat Kristen dalam situasi pendidikan Kristen yang didasari dengan Alkitab. Dalam pengertian ini dihubungkan dengan Alkitab karena perilaku komunitas Kristen tidak bisa terpisahkan dengan keyakinan pada Tuhan atas dasar kesaksian Alkitab sehingga begitu banyak manfaat psikologi dalam kehidupan sehari-hari. Situasi dalam pendidikan Kristen akan berbeda dengan situasi pendidikan umum yang nantinya akan berpengaruh dalam proses pendidikan.

\section{Peserta Didik Psikologis Pendidikan Kristen}

Dalam sebuah proses psikologis pendidikan Kristen, khusus bagian ini ditujukan kepada semua kelompok usia, misalnya : Jenjang Usia ke 1 : 0 - 12 Tahun, Jenjang Usia ke 2 
: 13 - 18 Tahun, Jenjang Usia ke $3: 19$ - 25 Tahun, Jenjang Usia ke 4: 26 - 35 Tahun, Jenjang Usia ke 5: 36 - 50 Tahun, Jenjang Usia ke 6: 50 - 65 Tahun dan Jenjang Usia ke 7: 65 Tahun keatas.

\section{Landasan Dasar Psikologis Pendidikan Kristen}

Psikologi memberikan sebuah masukan yang sangat berharga dalam bidang pendidikan, terutama dalam bagian ini fokus kepada pendidikan Kristus yang bersumber kepada karakter Kristus (Wadi and Selfina 2016).

\section{Mendekatkan Diri Kepada Tuhan}

Landasan psikologi pendidikan Kristen, pertama yaitu, mendekatkan diri kepada Tuhan. Kekuatan mendekatkan diri kepada Tuhan pasti akan sangat mempengaruhi seluruh keputusan dan perjalanan hidup orang percaya. Psikologi yang tertuang didalamnya adalah sebuah proses dimana seluruh jiwa berfokus kepada Tuhan dengan mengoptimalkan hidup mendekat kepada-Nya. Terutama bergantung penuh kepada kekuatan Roh Kudus yang menjadi sumber ketenangan hati, serta membantu proses pemahaman Firman Tuhan (Budiyana 2018b). Sebab orang yang dipimpin Roh Kudus akan mengalami pertumbuhan rohani, sehingga ia hidup sesuai dengan kebenaran Allah dan hidupnya menjadi saksi (Arifianto and sumiwi Rachmani 2020).

Makna mendekatkan diri kepada Tuhan, yaitu : landasan psikologi yang paling kuat dalam pendidikan Kristen adalah mendekatkan diri kepada Tuhan. Ini menjadi kekuatan spiritual yang sangat mendalam. Sering yang disebut hubungan yang intim dengan Tuhan. Dasar kehidupan yang mendekatkan diri kepada Tuhan, menjadi seluruh aspek kehidupan menjadi lebih tenang dan nyaman, seperti yang nyata dalam kebenaran Firman Tuhan (Yak. 4:8). Dan otomatis karakter mengalami perubahan makin baik, sesuai dengan prinsip-prinsip dalam Kotbah Yesus di Bukit (Mat. 5:6-12) (Boiliu et al. 2020). Hal ini bisa dilakukan dengan banyak berdoa, saat teduh dan serius dalam beribadah. Mengikuti Yesus atau menjadi orang percaya tidak cukup hanya menjadi pengikuti saja, namun menjadi seorang murid yang siap belajar dari gurunya dan ini yang disebut dengan sebuah pengalaman rohani (Boice 2015). Mengikuti Yesus bukan hanya sekedar pengetahuan. 


\section{Paulus Kunto Baskoro}

Tujuan mendekatkan diri kepada Tuhan, supaya hati lebih nyaman dan tenang, bisa mendengarkan suara Tuhan, bisa ketika membaca Firman, mendapatkan kekuatan ekstra dari Roh Kudus, membangun hubungan secara spiritual dengan Tuhan Yesus, memberikan keteladanan kepada generasi selanjutnya. Dan pengenalan akan Allah menentukan sebuah sikap yang akan muncul lewat kehidupannya (Andrianti 2014). Hasil mendekatkan diri kepada Tuhan yaitu dampak yang dirasakan ketika hidup mendekatkan diri kepada Tuhan, yaitu hati lebih tenang dan setiap keputusan bisa diambil dengan bijak dengan hikmat Tuhan. Hidup menjadi lebih kuat menghadapi segala tantangan dan pergumulan. Bahkan Roh Kudus menolong untuk memahami seluruh aspek kehidupan dan menuntun secara cermat hal-hal yang harus dibenahi (Budiyana 2018b).

\section{Membuka Diri Terhadap Nasihat}

Landasan psikologi pendidikan Kristen, kedua yaitu, membuka diri terhadap nasihat. Nasihat merupakan bagian yang memang kadang dimaknai kurang menyenangkan, padahal nasihat merupakan ceriman yang terbaik untuk sebuah pertumbuhan dan kedewasaan. Kuncinya memang membuka diri, maksudnya membuka hati untuk menerima masukan dan nasihat. Ini membuktikan sebuah kasih yang diwujudkan (Why. 3:19). Dan ujung pendidikan Kristen secara psikologi adalah Allah sendiri (Johannes 2020).

Makna membuka diri terhadap nasihat, yaitu dalam sebuah pendidikan memang tidak bisa dilepaskan dengan sebuah nasihat, teguran, masukan yang sangat bermanfaat bagi pertumbuhan dan pendewasaan., Yesus sendiri menyatakan bahwa siapa yang dikasihi ditegur dan dikasihi. Artinya memberikan masukkan atau nasihat serta teguran adalah salah salah bukti kasih. Dari sudut psikologi pendidikan Kristen, menjadi sangat penting untuk dipelajari, sebab secara psikologi ada banyak orang yang dinasihat dan menjadi marah, kecewa dan tidak nyaman di dalam hati. Itu sebabnya peran psikologi yang sangat penting dalam pendidikan Kristen yaitu membuka hati untuk dengan hati besar menerima setiap nasihat atau teguran. Teguran atau nasihat menjadi ladang dimana orang akan bisa menghargai orang dari pribadi yang memberikan nasihat. Ini merupakan sebuah kesungguhan dan manfaat yang tak ternilai yang bersemi dari lubuk hati seseorang untuk memberikan nasihat (Sugiyo 1996:29). Nasihat bisa berupa pesan Firman Tuhan yang disampaikan dalam kotbah Minggu, persekutuan doa, pelayanan bersama dan pesan media sosial yang disampaikan secara pribadi, sehingga hidup memiliki motivasi yang benar. Sebab motivasi 
yang benar memacu pertumbuhan dan semangat untuk bertumbuh (Saptono Yohanes Joko 2016).

Tujuan membuka diri terhadap nasihat, yaitu menjadi pribadi yang cepat bertumbuh dan dewasa dalam rohani, menunjukkan pribadi yang berhati besar, memberikan ruang untuk membangun sebuah hubungan makin baik, melihat sisi dimana Tuhan berbicara kepada seseorang demi kebaikan dirinya, hidup menjadi lebih baik serta disukai orang. Hasil membuka diri terhadap nasihat, adalah bagi pribadi yang membuka diri kepada nasihat yaitu disukai orang dan menjadi pribadi yang makin lebih cepat bertumbuh dan dewasa dibandingkan dengan yang lainnya, terlebih lagi mereka yang membuka diri terhadap nasihat adalah pribadi yang rendah hati.

\section{Membangun Integritas Sesuai Karakter Kristus}

Landasan psikologi pendidikan Kristen, ketiga yaitu, integritas sesuai karakter Kristus. Integritas adalah sebuah dasar dalam sebuah kehidupan. Integritas adalah kehidupan seseorang yang sesungguhnya, apa adanya, mulut dan hati tidka ada perbedaan. Psikologi pendidikan Kristen menjadi fundamental ketika integritas menjadi fokus dalam pendidikan, baik secara pribadi, keluarga dan gereja Tuhan, yang mengembangkan hubungan cinta kasih, bukan sebuah pemaksaan (Hutabarat 2019).

Makna membangun integritas sesuai karakter Kristus, yaitu integritas sebagai pribadi anak Allah adalah menjadi serupa dengan Kristus. Karakter Kristuslah yang menjadi bagian terpenting dalam pendidikan Kristen. Dan tujuan yang paling hakiki dalam pendidikan Kristen adalah sebuah perubahan yang makin lebih baik, menjadi serupa dengan Kristus serta memiliki karakter ilahi. Psikologi pendidikan Kristen yang harus dikaji yaitu kehidupan seseorang yang sesungguhnya, bagaimana mereka bersikap, bertutur kata dan memikirkan sesuatu yang sentralnya adalah karakter Kristus (Hauck 1986:14). Sebab ada banyak orang percaya yang hidupnya tidak sesuai dengan karakter Kristus, sehingga menjadikan nama Tuhan tidak dipermuliakan. Integritas memang harus dibangun dan dasarnya adalah kebenaran Firman Tuhan. Integritas yang harus dibangun sesuai karakter Yesus, yaitu hidup dalam kejujuran, dapat dipercaya, rendah hati, fokus untuk siap berkorban. Ketika orang percaya membaca Firman Tuhan serta hidup berpadanan dengan Firman Tuhan, maka yang 
terjadi hidupnya akan mengalami perubahan serta hidup menjadi teladan. Seperti yang dinyatakan dalam 1 Timotius 4:11-16.

Tujuan membangun integritas sesuai karakter Kristus, yaitu menjadi pribadi yang memiliki karakter Yesus, menjadi teladan bagi banyak orang, memiliki kehidupan yang dapat dipercaya dalam segala hal, pribadi yang senantiasa menjadikan Firman sentral pegangan hidupnya, nama Yesus dipermuliakan. Ujungnya ada dalam keluarga yang sangat berperan mewujudkan keteladanan karakter Kristus (Hutabarat 2019). Hasil membangun integritas sesuai karakter Kristus adalah pendidikan Kristen harus menjadi manusia, khususnya orang percaya menjadi pribadi yang berintegritas tinggi. Hidup yang penuh kejujuran dan menjadi berkat bagi banyak orang, serta Yesus dipermuliakan.

\section{Memberikan Pendapat Sesuai Kebenaran Firman Tuhan}

Landasan psikologi pendidikan Kristen, keempat yaitu, memberikan pendapat sesuai kebenaran Firman Tuhan. Makna pendapat sesuai kebenaran Firman Tuhan. Banyak orang percaya cenderung untuk memberikan pendapat yang tidak sesuai dengan kebenaran Firman Tuhan dan menghakimi. Perbendaharaan hati yang tidak beres pasti akan mengeluarkan pendapat yang tidak beres serta tidak sesuai dengan Firman Tuhan. Psikologi pendidikan Kristen menyoroti bahwa hati menjadi sentral dari setiap pendapat yang akan dikeluarkan (Am. 4:23). Hati yang bagus akan menghasilkan pendapat yang bagus. Lidah menjadi kunci sebuah kehidupan (Ams. 18:21). Usulan secara psikologi pendidikan yaitu ketika hati beres maka pendapat akan sesuai dengan kebenaran Firman Tuhan. Untuk hati beres, biarlah hati selalu hidup dituntun oleh Firman dan hidup dalam pimpinan Roh Kudus. Roh Kudus akan memberikan hikmat untuk berkata-kata yang sesuai dengan kebenaran Firman Tuhan, sehingga menjadi pribadi yang membangun (Anon 2012.:665).

Tujuan pendapat sesuai kebenaran Firman Tuhan yaitu pribadi yang mendengar diberkati, hidup senantiasa dalam tuntunan Firman Tuhan dan Roh Kudus, perkataan akan membangun dan menguatkan, menjadi terarah dan fokus menggenapi rencana Tuhan, orang selalu disegarkan. Dan yang lebih sangat penting potensi yang keluar adalah dari kebenaran Firman Tuhan (Situmorang 2015). Hasil pendapat sesuai kebenaran Firman Tuhan. Firman Tuhan adalah sesuatu yang menguatkan, menghiburkan dan menjadi tuntunan kehidupan. Pendapat yang sesuai dengan Firman akan menjadi pribadi, keluarga maupun gereja dalam 
pendidikan Kristen menjadi lebih terarah dan memberkati. Psikologi pendidikan Kristen harus menjadi sentral supaya hati selalu memiliki sikap hati yang benar dalam kondisi apapun.

\section{Memberikan Konseling yang Efektif}

Landasan psikologi pendidikan Kristen, kelima yaitu, konseling yang efektif. Sebab psikologi berhubungan dengan kejiwaan, sikap atau perilaku seseorang. Ini semua berfungsi untuk menolong setiap orang bertumbuh dan mengenali siapa dirinya yang sesungguhnya serta meningkatkan potensi dirinya. Dan sebetulnya dari dalam keluarga, bisa dimulai praktek konseling yang efektif ini, sebab keluarga tempat terbaik dalam pendidikan agama Kristen (Djami 2012).

Makna memberikan konseling yang efektif yaitu ketika sikap yang dimiliki mau untuk saling berbagi atau sharring setiap hal yang dihadapi dalam kehidupan, baik secara pribadi, keluarga atau komunitas orang percaya. Beberapa pengalaman yang sering terjadi adalah ketika orang mengalami problem kejiwaan, emosi, sikap dan perilaku, maka akhirnya hidupnya makin menjauh dari Tuhan dan akhirnya meninggalkan Tuhan. Aspek-aspek inilah yang secara psikologi sangat mempengaruhi kehidupan seseorang, ada yang mengalami gangguan stres bahkan frustasi. Kehadiran konseling yang efektif menjadi dasar untuk menolong mereka pulih dan kembali kepada kasih mula-mula dalam Kristus. Hal ini bisa dilakukan oleh pemimpin Kristus, pemimpin kelompok sel atau saudara seiman yang rohaninya lebih dewasa. Sehingga secara psikologi pendidikan Kristen, dapat memahami emosi, kejiwaan, sikap dan perilaku hidup yang terjadi dan mendapatkan solusi yang tepat serta efektif sesuai dengan kebenaran Firman Tuhan. Ini adalah jalan menuju keutuhan yaitu pengudusan spiritual (Mack 2002:27). Yesus menjadi penasihat utama atas segala sesuatu yang terjadi dalam kehidupan kita.

Tujuan memberikan konseling yang efektif adalah membantu menemukan akar masalah yang sesungguhnya, menolong kembali untuk memulihkan jati diri seseorang, membangun kepercayaan diri, memberikan pendampingan sehingga merasa sangat nyaman, kembali kepada kasih mula-mula kepada Yesus. Hasil memberikan konseling yang efektif yaitu pribadi yang ditolong akan makin luar biasa dalam hidupnya sebab merasakan kasih Bapa dari kita dan menjadi mereka menjadi berharga kembali, merasa diterima dan 
difungsikan sesuai dengan karunianya. Bahkan menjadikan pribadi yang mengerti cara keajaiban Tuhan dalam menolong kehidupannya.

\section{Merumuskan Visi Pengajaran}

Landasan psikologi pendidikan Kristen, keenam, yaitu, merumuskan visi pengajaran. Visi menjadi bagian terpenting dalam diri seseorang atau kelompok, terlebih gereja. Visi yang jelas akan membuat seluruh gerakan dan program menjadi lebih terarah. Tanpa visi menjadi liar rakyat. Visi adalah sebuah kemampuan melihat jauh ke depan tentang sebuah tujuan yang sangat mulia serta mencapainya dengan pertolongan tangan Tuhan.(Anon 2012.) Merumuskan visi menjadi salah satu bagian dalam psikologi perdidikan Kristen, karena membutuhkan kekuatan pengajaran, yang berfokus kepada kebenaran Firman Tuhan, sebab ini kekuatan seorang pendidik (Situmorang 2018).

Makna merumuskan visi pengajaran, adalah pengajaran menjadi salah satu bagian terpenting dalam psikologi pendidikan Kristen, apalagi ada unsur pendidikan. Pendidikan pasti berkaitan erat dengan pengajaran. Pengajaran yang terbaik harus disertai dengan visi yang baik. Visi terarah, maka pengajaran menjadi terarah. Psikologi pendidikan Kristen memberikan rumuskan visi pengajaran supaya setiap agenda yang dibuat menjadi efektif. Fungsi sebuah rumuskan harus bersentral dari kebenaran Firman Tuhan. Ini menjadi mudah dalam pelaksanaan jika dikerjakan dengan sebuah tim yang solid dan memahami cara kerja yang ada.

Tujuan merumuskan visi pengajaran, yaitu membuat fungsi pendidikan terarah, tidak membuat kebingungan dalam melangkah, kesiapan tim dalam menunaikan setiap tugas yang dipercayakan.

Hasil merumuskan visi pengajaran adalah kekuatan hasil dari merumuskan visi pengajaran yaitu memudahkan seluruh anggota untuk melaksanakan dan bekerjasama menuju visi yang sudah ditetapkan dan setiap tuntunan menjadi lebih mudah dipahami. Ketika segalanya mudah dan terpahami, maka menjadikan pendidikan lebih maksimal kepada setiap orang percaya. 


\section{Menerapkan Pelaksanaan Amanat Agung}

Landasan psikologi pendidikan Kristen, ketujuh yaitu, menerapkan pelaksanaan amanat agung. Pelaksanaan amanat agung dalam Matius 28:19-20 menjadi bagian terpenting untuk psikologi pendidikan Kristen. Dan ini bukan hanya tugas orang yang didik, namun juga semua pendidik ikut berjuang bersama (Andriani 2013). Pendidikan Kristen menjadi sangat memiliki nyawa ketika amanat agung menjadi sentral penerapan kehidupan orang percaya. Karena amanat agung adalah perintah yang harus dikerjakan setiap orang percaya. Amanat agung menjadi bukti nyata psikologi orang percaya dari sikap dan perilakunya yang senada dengan denyut nadi Allah menjadi semua bangsa adalah murid Yesus. Allah dengan hati setiap orang percaya memahami misi besar untuk setiap orang percaya menjadi pribadi yang mengasihi dan terus memberitakan Injil serta menjadi teladan (Sagala 2017).

Makna menerapkan pelaksanaan amanat agung, adalah Yesus memberikan sebuah perintah yang sangat fundamental dan penting dalam kehidupan orang percaya yang harus dikerjakan dalam sepanjang zaman. Psikologi yang terjadi dalam pendidikan Kristen, menyaksikan banyak orang tidak terlalu menyukai konsep amanat agung. Itu sebabnya sebagai orang percaya, terlebih bisa dimulai dalam sebuah keluarga yang memiliki hati misi dan memahami konsep ini, mari menjadi pelaku yang menerapkan pelaksanaan amanat agung dengan membawa banyak orang kepada Yesus, menjadikan semua bangsa murid dan mengajar mereka untuk melakukan perintah Tuhan yaitu amanat agung (Hastuti 2013). Orang Kristen yang taat dalam perbuatan dapat digambarkan sebagai salib Kristus. Dimana kasih itu berkuasa dan bergelora untuk akhirnya setiap orang percaya juga memberitakan salib Yesus (Budiyana 2018a).

Tujuan menerapkan pelaksanaan amanat agung yaitu memberikan hati untuk mengasihi jiwa-jiwa, hidup sesuai dengan rencana dan hati Tuhan, banyak murid yang dihasilkan, memiliki keberanian melangkah karena Roh Kudus yang memberi kuasa, makin banyak orang percaya Yesus dan diselamatkan. Hasil menerapkan pelaksanaan amanat agung yaitu dampak yang sangat besar ketika pribadi, keluarga, gereja fokus menunaikan amanat agung, sebab ini adalah hati Tuhan bagi seluruh umat manusia, bahwa semua percaya kepada Yesus dan menikmati hidup kekal. Amanat agung merupakan kekuatan yang sangat luar biasa jika dikerjakan dengan penuh sukacita, sebab lewat amanat agung akan banyak orang menerima Yesus sebagai Tuhan dan Juruselamat dan murid dihasilkan dengan multiplikasi besar. Sehingga setiap orang percaya menjadi pribadi yang sejati dalam Yesus. 


\section{Relevansinya Psikologis Pendidikan Kristen dalam Pendidikan Kristen Masa Kini}

Bagi keluarga Kristen, yaitu Pertama, psikologi pendidikan Kristen menjadikan setiap keluarga menjadi pribadi yang makin mendekatkan diri kepada Yesus dengan terus setia dalam beribadah, memiliki jam saat teduh dan jam doa secara pribadi, serta membangun mezbah keluarga yang rutin sehingga komunikasi secara horizontal serta vertikal terjalin dengan efektif. Kekuatan sebuah hubungan roh akan menjadi lebih dalam dibanding kekuatan hubungan secara jasmani. Tuhan yang menjadi sentral kehidupan. Kedua, setiap anggota keluarga menjadi keluarga yang lebih terbuka dan sangat cair dalam komunikasi. Sehingga tidak ada yang tersembunyi dalam kehidupan rumah tangga Kristen. Menjadi rumah tangga yang nyaman, semua bertumbuh dengan sukacita dalam keluarga tersebut. Orang menyaksikan sebuah pemandangan baru dalam kehidupan rumah tangga di lingkungan tertentu. Nama Tuhanlah yang akan dipermuliakan. Ketiga, setiap keluarga membangun integritas dalam Kristus. Masing-masing anggota keluarga menjadi pribadi yang dapat dipercaya.

Bagi orang percaya yaitu, Pertama, orang percaya menjadi pribadi yang memiliki perkataan yang sangat membangun dan menguatkan. Sehingga banyak orang diberkati dengan perkataannya. Perkataan yang membangun akan menjadi kehidupan penuh dengan damai sejahtera. Kedua, psikologi pendidikan Kristen bagi orang percaya dapat dilihat dengan hidup menjadi garam dan terang dunia dalam perkataan, kemurahan, kebaikan. Ketiga, kesatuan orang percaya dalam membangun kehidupan yang dengan semangat menunaikan amanat agung Kristus dengan penuh keberanian. Sehingga banyak murid yang dihasilkan dan orang percaya terus bertambah. Serta mempersiapkan jemaat untuk kedatangan Yesus kali kedua (Utomo 2016).

Bagi gereja, yaitu pertama, gereja menjadi komunitas yang sangat menyenangkan karena memiliki perkataan-perkataan yang membangun dan memberikan kekekuatan yang utuh serta sempurna. Kedua, memiliki visi yang jelas dalam penjabaran yang utuh, sehingga gereja bisa lebih fokus dalam mengerjakan rencana Allah. Visi yang jelas dimulai dari pemimpin gereja yang dapat diterima oleh setiap anggota gereja dan mengerjakan bersamasama menuju kesempurnaan dalam Kristus. Ketiga, gereja memiliki keteguhan hati untuk bersama menunaikan tugas amanat agung dan bergerak bersama untuk membawa jiwa-jiwa kepada Kristus. Murid dihasilkan dengan maksimal dan makin banyak orang yang terlibat 
dalam pelayanan sesuai dengan potensi dan karunianya, yang juga dikuatkan dengan konsep ibadah penuh kualitas (Christimoty 2019).

\section{REKOMENDASI PENGEMBANGAN PENELITIAN}

Penulis berharap hasil penelitian ini dapat bermanfaat bagi gereja, lembaga pendidikan dan terlebih kepada keluarga. Kiranya saran atau kritik dapat diberikan kepada penulis oleh semua pembaca agar dikesempatan selanjutnya penulis dapat lebih lagi dalam mengembangkan kemampuan yang telah diberikan oleh Tuhan. Penelitian ini masih dapat dikembangkan dengan melihat relevansi penelitian, dengan fakta-fakta di tahun-tahun selanjutnya, oleh orang-orang yang mau menguji atau mengembangkannya. Kemudian, penulis juga berharap kiranya penelitian ini dapat menjadi referensi dari penulis-penulis berikutnya yang sedang menulis tentang topik-topik seputar pembahasan yang ada pada artikel ini.

\section{KESIMPULAN}

Psikologi pendidikan Kristen merupakan bagian yang sangat penting dalam membangun sebuah pertumbuhan dan kedewasaan dalam Kristus. Psikologi pendidikan Kristen sangat diperlukan. Sebab dengan memahami psikologinya, maka pendekatan yang dilakukan dalam kerangka pendidikan akan sangat tepat dan efektif. Beraneka ragam pribadi yang harus dibimbing, dituntun dan diarahkan. Setiap pribadi orang percaya memiliki karakteristik, kejiwaan, emosi, sikap dan perilaku yang pasti berbeda-beda. Namun dengan landasan psikologi yang sama dan ideal berdasarkan Firman Tuhan maka pendidikan Kristen baik secara pribadi, keluarga maupun dalam gereja akan berjalan dengan efektif dan maksimal, nama Tuhan dipermuliakan dan menjadi serupa dengan Kristus.

Untuk memahami dengan utuh psikologi pendidikan Kristen, maka perlu dikaji lebih dahulu pengertian psikologi pendidikan Kristen. Yang diawali dengan memahami makna pendidikan Kristen yaitu arti pendidikan Kristen, fungsi pendidikan Kristen, ciri khas pendidikan Kristen. Tinjauan selanjutnya adalah makna psikologi Pendidikan yaitu arti psikologi dan psikologi pendidikan, sejarah psikologis pendidikan, fungsi psikologi pendidikan, wilayah terapan psikologi pendidikan dengan melibatkan seluruh elemen usia yang akan dibimbing dalam pendidikan Kristen. Jadi arti psikologi pendidikan Kristen yaitu memahami bentuk-bentuk gejala kejiwaan, sikap dan perilaku orang Kristen, baik secara 
pribadi atau dalam lingkungan gereja, dalam proses pendidikan atau selama mengikuti belajar mengajar, sehingga kelihatan potensinya dan mengembangkan potensi yang sesungguhnya untuk memfokuskan individu tersebut dalam semua tujuan pembelajaran dengan hasil yang sangat efektif dan maksimal demi kemuliaan nama Tuhan dan karakter Kristus nyata.

Dan landasan dasar psikologis pendidikan Kristen yang disajikan dan menjadi referensi dalam kehidupan orang percaya yaitu : Pertama, mendekatkan diri kepada Tuhan; Kedua, membuka diri terhadap nasihat; Ketiga, membangun integritas sesuai karakter Kristus; Keempat, memberikan pendapat sesuai kebenaran Firman Tuhan; Kelima, memberikan konseling yang efektif; Keenam : merumuskan visi pengajaran; Ketujuh : menerapkan Pelaksanaan amanat agung. Kemudian dari ketujuh landasan psikologi pendidikan Kristen ditarik sebuah relevansinya psikologis kendidikan Kristen dalam pendidikan Kristen masa kini bagi orang percaya, keluarga dan gereja Tuhan. Akhirnya semua akan mendapatkan semua keutuhan pendidikan yang bersentral kepada Tuhan menjadi serupa dengan Kristus dan memiliki karakter Kristus. Nama Tuhan Yesus dipermuliakan.

\section{BIODATA}

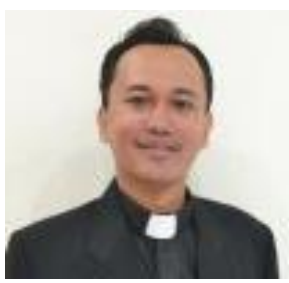

Paulus Kunto Baskoro adalah seorang penulis dari Sekolah Tinggi Teologi Injili Indonesia. Pada Tulisannya ia sering menekankan makna teologis dari setiap topik-topik yang diangkatnya. Dia juga adalah sosok yang terbuka, suka berkolaborasi dengan penulis-penulis di luar lembaga pendidikan yang menaunginya.

\section{Paulus Kunto Baskoro}

Surel : paulusbaskoro1177@gmail.com

\section{REFERENSI}

Andriani, Sarah. 2013. "Refleksi Guru Pendidikan Agama Kristen Sebagai Misionaris Di Dalam Pendidikan.” Jurnal Antusias: Jurnal Teologi Dan Pelayanan.

Andrianti, Sarah. 2014. "Pendekatan Pembelajaran Berpusat Pada Siswa Dalam Pendidikan Agama Kristen Sebagai Implementasi Kurikulum 2013.” Jurnal Antusias.

Anon. n.d. Pola Hidup Kristen. Malang: Gandum Mas.

Arifianto, Yonatan. 2020. "Deskripsi Sejarah Konflik Horizontal Orang Yahudi Dan Samaria.” PASCA : Jurnal Teologi Dan Pendidikan Agama Kristen 16(1):33-39.

Arifianto, Yonatan Alex. 2020a. "Pentingnya Pendidikan Kristen Dalam Membangun 
Kerohanian Keluarga Di Masa Pandemi Covid-19.” Regula Fidei Jurnal Pendidikan Agama Kristen 5(2).

Arifianto, Yonatan Alex. 2020b. "Studi Deskriptif 1 Timotius 4:1-16 Tentang Pelayan Kristus Yang Baik." JURNAL TEOLOGI RAHMAT 6(1):66-77.

Arifianto, Yonatan Alex, and Asih sumiwi Rachmani. 2020. "Peran Roh Kudus Dalam Menuntun Orang Percaya Kepada Seluruh Kebenaran Berdasarkan Yohanes 16: 13.” Jurnal Diegesis 3(1):1-12.

Boice, James Montgomery. 2015. Dasar-Dasar Iman Kristen. Surabaya: Penerbit Momentum (Momentum Christian Literature).

Boiliu, Ibrahim, Aeron Frior Sihombing, Christina M. Samosir, and Fredy Simanjuntak. 2020. "Mengajarkan Pendidikan Karakter Melalui Matius 5 : 6-12.” KURIOS (Jurnal Teologi Dan Pendidikan Agama Kristen).

Budiyana, Hardi. 2017. Dasar-Dasar Pendidikan Agama Kristen. Cetakan ke. Surakarta: STT Berita Hidup.

Budiyana, Hardi. 2018a. Pendidikan Orang Dewasa. Cetakan ke. Surakarta: STT Berita Hidup.

Budiyana, Hardi. 2018b. "Roh Kudus Dalam Proses Pembelajaran Pendidikankristen Mewujudkan Pengajaran Kristen Yang Mengandung Nilai Kekal.” Jurnal Teologi Berita Hidup 1(1).

Casriarno, Adida, and Demianus Nataniel. 2020. "DINAMIKA PENDIDIKAN AGAMA KRISTEN DI TENGAH WABAH CORONA: SEBUAH REFLEKSI BERDASARKAN PENGAJARAN PAULUS DALAM GALATIA 6:2." Jurnal Abdiel: Khazanah Pemikiran Teologi, Pendidikan Agama Kristen, Dan Musik Gereja.

Christimoty, Debora Nugrahenny. 2019. "Teologi Ibadah Dan Kualitas Penyelenggaraaan Ibadah: Sebuah Pengantar.” PASCA : Jurnal Teologi Dan Pendidikan Agama Kristen.

Djami, Marla Marisa. 2012. "Pencarian Identitas Diri Dan Pertumbuhan Iman Remaja." STAKN Kupang.

Ermindyawati, Lilis. 2019. "Peranan Guru Pendidikan Agama Kristen Terhadap Perilaku Siswa-Siswi Di SD Negeri 01 Ujung Watu Jepara.” FIDEI: Jurnal Teologi Sistematika Dan Praktika 2(1):40-61.

Hastuti, Ruwi. 2013. "Pendidikan Agama Kristen Dalam Keluarga Sebagai Pusat Bermisi." Jurnal Antusias 2(4):23-68.

Hauck, Paul. 1986. Psikologi Populer, Bagaimana Mencintai Dan Agar Dicintai. Jakarta: Arcan. 
Heath, W. Stanley. 1995. Psikologi Yang Sebenarnya. Yogyakarta: Yayasan Andi.

Hendro H. siburian, Arif Wicaksono. 2019. "Makna Belajar Dalam Perjanjian Lama Dan Implementasinya Bagi PAK Masa Kini, Fidei: No. 2.” Jurnal Teologi Sistematika Dan Praktika 2.

Hutabarat, Oditha R. 2019. "MENDIDIK ANAK BERKARAKTER KRISTEN MENGATASI KEKERASAN.” Voice of Wesley: Jurnal Ilmiah Musik Dan Agama.

Johannes, Nathalia Yohanna. 2020. "PENINGKATAN HASIL BELAJAR PENDIDIKAN AGAMA KRISTEN MELALUI MODEL PEMBELAJARAN KOOPERATIF TIPE TWO STAY TWO STRAY BAGI SISWA KELAS 5 SD NEGERI TOISAPU." PEDAGOGIKA: Jurnal Pedagogika Dan Dinamika Pendidikan.

KBBI. 2002. Kamus Besar Bahasa Indonesia. Jakarta: Balai Pustaka.

Lase, Delipiter, and Etty Destinawati Hulu. 2020. "Dimensi Spritualitas Dalam Kompetensi Kepribadian Guru Pendidikan Agama Kristen." SUNDERMANN: Jurnal Ilmiah Teologi, Pendidikan, Sains, Humaniora Dan Kebudayaan.

Mack, John MacArthur dan Wayne A. 2002. Pengantar Konseling Alkitabiah. Malang: Gandum Mas.

Pazmino, Robert W. 2016. Fondasi Pendidikan Kristen. Jakarta: BPK Gunung Mulia.

Sagala, Lenda Dabora. 2017. "Peran Pendidikan Agama Kristen Dalam Menghadapi Perubahan Sosial.” Jurnal Simpson: Jurnal Teologi Dan Pendidikan Agama Kristen 1(1):48.

Sahartian, Santy. 2018. "Pemahaman Guru Pendidikan Agama Kristen Tentang II Timotius 3:10 Terhadap Peningkatan Kecerdasan Spiritual Anak Didik." FIDEI: Jurnal Teologi Sistematika Dan Praktika.

Samosir, Rorua. 2019. "Guru Pendidikan Agama Kristen Yang Profesional.” Jurnal Pionir LPPM Universitas Asahan.

Saptono Yohanes Joko. 2016. "Motivasi Dan Keberhasilan Belajar Siswa.” Jurnal Pendidikan Agama Kristen I(1):189-212.

Situmorang, Solida. 2015. "Desain Pengajaran Yang Alkitabiah.” KERUSSO: Jurnal Teologi Dan Pendidikan Agama Kristen.

Situmorang, Solida. 2018. "Integritas Mengajar Guru Pendidikan Agama Kristen.” K E R U S $S O$.

Sugiyo, Teha. 1996. Keluarga Sebagai Sekolah Cinta. Bandung: Lembaga Literatur Baptis.

Tafonao, Talizaro. 2018. "Peran Pendidikan Agama Kristen Dalam Keluarga Terhadap Perilaku Anak.” Edudikara: Jurnal Pendidikan Dan Pembelajaran. 
Telaumbanua, Arozatulo. 2018. "Peranan Guru Pendidikan Agama Kristen Dalam Membentuk Karakter Siswa.” FIDEI: Jurnal Teologi Sistematika Dan Praktika.

Utomo, Bimo Setyo. 2016. "Menggagas Penerapan Pengajaran Tentang Akhir Zaman Dalam Pendidikan Agama Kristen Di Tingkat Sekolah Dasar Dan Menengah Pertama." DUNAMIS: Jurnal Penelitian Teologi Dan Pendidikan Kristiani.

Wadi, Elsyana Nelce, and Elisabet Selfina. 2016. "Peran Orang Tua Sebagai Keluarga Cyber Smart Dalam Mengajarkan Pendidikan Kristen Pada Remaja GKII Ebenhaezer Sentani Jayapura Papua.” Jurnal Jaffray.

Widianing, Oda Judithia. 2018. "Pendidikan Kristen Di Sekolah: Sebuah Tugas Ilahi Dalam Memuridkan Jiwa.” Jurnal Teologi Berita Hidup.

Zaluchu, Sonny Eli. 2020. "Strategi Penelitian Kualitatif Dan Kuantitatif Di Dalam Penelitian Agama.” Evangelikal: Jurnal Teologi Injili Dan Pembinaan Warga Jemaat 4(1):28-38. 